6-1-2005

\title{
The Analogy of Tradition: Method and Theological Judgment
}

John E. Thiel

Fairfield University, jethiel@fairfield.edu

Follow this and additional works at: https://digitalcommons.fairfield.edu/religiousstudies-facultypubs

\section{Peer Reviewed}

\section{Repository Citation}

Thiel, John E., "The Analogy of Tradition: Method and Theological Judgment" (2005). Religious Studies

Faculty Publications. 42.

https://digitalcommons.fairfield.edu/religiousstudies-facultypubs/42

\section{Published Citation}

Thiel, John E. "The Analogy of Tradition: Method and Theological Judgment." Theological Studies 66.2 (2005): 358-380.

This item has been accepted for inclusion in DigitalCommons@Fairfield by an authorized administrator of DigitalCommons@Fairfield. It is brought to you by DigitalCommons@Fairfield with permission from the rightsholder(s) and is protected by copyright and/or related rights. You are free to use this item in any way that is permitted by the copyright and related rights legislation that applies to your use. For other uses, you need to obtain permission from the rights-holder(s) directly, unless additional rights are indicated by a Creative Commons license in the record and/or on the work itself. For more information, please contact digitalcommons@fairfield.edu. 


\title{
THE ANALOGY OF TRADITION: METHOD AND THEOLOGICAL JUDGMENT
}

\author{
JOHN E. THIEL
}

\begin{abstract}
[The author examines a basic question for theological inquiry: how is congruence between past and present meaning achieved in tradition and in theological judgment? He begins by criticizing the account of traditional continuity offered in the recent work of Kathryn Tanner and by considering the limits of correlation in explaining congruence in theological judgment. Constructively, he proposes an understanding of method as a pragmatics of tradition in which a certain use of analogy accounts for traditional and theological congruence.]
\end{abstract}

$\mathrm{T}$ HE DEVELOPMENT OF DOCTRINE is an assumption of modern theology. Theologians typically understand their work as the practice of doctrinal development, and so as the practice of the assumption that doctrine develops. One would think that the basic practices that enact a field's assumptions would merit the closest scrutiny, since they take shape as disciplinary performance itself. To the contrary, the assumed, by its very nature, tends to pass unexamined before the critical eye. This often occurs because scholars think that basic practices obviously discharge the assumptions to which they are beholden. The disciplinary practice is taken to be so simple a rendition of the assumptions that a critical account of how the practice does what it does is deemed unnecessary. The practice is undertaken as though it transcends method, sometimes even when the practice ostensibly enacts a method. Yet, on closer examination, the connection between practice and assumptions proves to be tenuous at best. A good example of such latitude in the field of theology can be found in how theologians practice the assumption of doctrinal development.

Theologians engage in this interpretive practice all the time. But how, exactly, does this practice happen, and how, exactly, does one know when it is accomplished well or poorly? These are difficult questions to answer.

JoHN E. THIEL received his Ph.D. from McMaster University. He is currently professor of religious studies at Fairfield University, Fairfield, Connecticut. His most recent books include God, Evil, and Innocent Suffering: A Theological Reflection (Crossroad, 2002) and Senses of Tradition: Continuity and Development in Catholic Faith (Oxford University, 2000). At the present time he is working on a book dealing with eschatology. 
One might begin by objecting that the questions are not posed very well, since any answer would never be a matter of "exactly." As Schleiermacher observed long ago, the practice of interpretation is not a science but an art. ${ }^{1}$ This art is a matter of judgment that requires the theologian to bridge the distance, conceptually and expressively, between ancient meaning and its contemporary appropriation. It would not be difficult, however, to say exactly how interpretive practice fails. The extremes of the interpretive spectrum-mindless repetition and "anything goes" speculation-would fail for lack of judiciousness, by relinquishing the task of interpretation itself. It may be the case that saying how interpretive judgment takes place, exactly, between these extremes is neither possible nor even desirable, as long as method provides some general guidelines for the hermeneutical task to proceed meaningfully.

But even if "exactly" happily eludes us, the goal of this article is to say more nearly how the assumption of doctrinal development is practiced in theological reflection. I argue for a more detailed account of the interpretive practice at the heart of theological reflection, at the very point that theological judgment claims success. This more detailed account could be understood as a theological method, one that I will call the "analogy of tradition." I make no claims for the novelty of this method. I think that contemporary theologians actually do practice this method, though perhaps without being conscious of doing so. Before I sketch this method and argue for its advantages, I will first define the theological problem that it addresses.

\section{CONGRUENCE IN TRADITION AND IN THEOLOGICAL JUDGMENT}

Any theological judgment attempts to reconcile the relevance of contemporary concerns with faithfulness to the past. Such a judgment posits a congruent relationship between past and present that may be weighted more on the authority of the past or more on the pressing needs of the moment, resulting in theological positions that are, respectively, more conservative or more liberal. By "congruent" I mean an interpretive relationship characterized by meaningful continuity between the authoritative past and the contemporary theological claim, a continuity that believers understand as the unity of tradition and the basis of Christian faithfulness through the ages. But how is this congruence in tradition achieved? And, more specifically, how does this congruence come to be formulated in a theological judgment? The first question has not troubled modern theol-

\footnotetext{
${ }^{1}$ Friedrich Schleiermacher, Hermeneutik, ed. Heinz Kimmerle (Heidelberg: Carl Winter Universitätsverlag, 1974) 75.
} 
ogy. As I have already noted, the development of doctrine is an assumption of modern theology, and one that takes the congruence of developing tradition for granted as one of its authentic traits. The second question has been answered by any number of modern theorists on theological method who have explained how congruence is formulated in theological judgment. It would seem, then, that these questions have proven unproblematic, the first because it has not been raised and the second because it has been answered so easily and so often. I will argue that the assumption of traditional congruence requires the careful justification that it typically has lacked, and that the methodological explanations of congruence in theological judgment typically are rather thin since the congruence they explain is largely assumed. With regard to the first question, the work of Kathryn Tanner can help us to appreciate why the assumption of congruence in tradition is a large assumption indeed, and one that should not be made uncritically.

In her important book Theories of Culture: A New Agenda for Theology, Tanner considers the implications of postmodern cultural theory for Christian claims about the continuity of tradition. If one truly appreciates the remarkable diversity that flourishes in any culture, Tanner argues, then one should be suspicious of customary Christian beliefs about the unity of the cultural meaning system that Christians call "tradition." It may be tempting to think of cultures as the "wholes" they are usually made out to be, by insiders and outsiders alike. Understood, though, as the practice of everyday life, a culture takes shape as a limitless proliferation of meaning that defies the unity, stability, and continuity over time that a structuralist mindset projects onto it. Traditional conceptions of culture, including those of modern anthropologists, tend to deny internal difference, allowing difference to appear only at the margins of society where strained encounter with other cultures reifies the myth of internal homogeneity. A postmodern cultural theory, faithful to the evidence of cultural life "on the ground," recognizes the remarkable array of different beliefs and practices that any culture is. Tanner maintains that extensive pluralism does not subvert the possibility of cultural consensus. But in actual cultural life that consensus "becomes ... extremely minimalistic: it forms the basis for conflict as much as it forms the basis for shared beliefs and sentiments." ${ }^{2}$ Culture, she proposes, is better conceived as a locus of contested engagement than as a coalescence of shared beliefs and practices.

The assumption of congruence in tradition meets a significant challenge in Tanner's position. A religious tradition, she avers, behaves just as any culture does. In spite of its portrayal as a unified whole, it is actually an

\footnotetext{
${ }^{2}$ Kathryn Tanner, Theories of Culture: A New Agenda for Theology (Minneapolis: Fortress, 1997) 57.
} 
amalgam of beliefs and practices that hangs together only in the loosest ways. Christian tradition is as porous as any culture. Its boundaries are fluid and permeable; its cohesion little more than acts of imagination and power serving a host of interests. The unity of Christian tradition, Tanner points out, cannot be supported by historical investigation since such study documents Christian disagreement through the ages about virtually every matter of valued belief and practice. Even the most basic beliefs of Christianity-such as the belief in one God-instantly proliferate when extended to other beliefs, like God's relationship to the world, or to practices, like what moral faithfulness to the one God really means. ${ }^{3}$

Tanner does not conclude that Christian tradition is a chimera, only that it is not some special case exempt from the ordinary workings of culture. Christianity "may be called a tradition in the sense it amounts to a whole ongoing way of life." But so understood, "talk of tradition is just a way of formulating ... questions about Christian identity ... and is not a way of answering them." 4 She proposes that the unity of Christian tradition lies in shared concerns among Christians about the "materials" that they value-such as texts, creedal formulae, and rituals-rather than in agreement about what these materials mean. Moreover, the unity of tradition, and so Christian identity, lies in the commitment Christians make to the ongoing task of arguing about the meaning of their materials, "[g]reat diversity and conflict of particular interpretations [being] ... more often than not the result." 5

If Tanner is correct, then the assumption of congruence in tradition cannot be justified by cultural behavior. Traditional congruence presumes some level of semantic agreement through the ages. Tanner's analysis concludes that such congruence is absent both diachronically and synchronically. Tanner makes this point well by criticizing the assumption of congruence in premodern and modern notions of tradition. Such "accounts of tradition make continuity in either traditional materials or the process of transmission a presumption by isolating something from the vicissitudes of history to guarantee it." Attending specifically to the modern conception of tradition as development, Tanner observes that "[g]reater attention is given here to the process of transmission, but it is a process in which, it is hoped, an identity of content or substance in what is transmitted is retained." In such a view, difference in any moment of historical development "amounts only to making explicit what was implicit before." The

${ }^{3}$ Ibid. 146. See Tanner's important study of the diversity of ethical belief in the one God. Kathryn Tanner, The Politics of God: Christian Theologies and Social Justice (Minneapolis: Fortress, 1992).

${ }^{4}$ Ibid. 128.

${ }^{6}$ Ibid. 131.

${ }^{5}$ Ibid. 153. 
metaphor of organic life promotes the hope for continuity by imaging a history in which "later developments are somehow present in a nascent form earlier," just as later growth manifests the substance of the original seed. ${ }^{7}$ Tanner sees in this modern theory an unwillingness to acknowledge the real evidence of history:

Thus, when organic life is the model for understanding tradition, no amount of diversity in what Christians say and do need dislodge the presumption of their agreement so long as they all seem members of an historically continuous, selfgenerating sequence of events; historical evidence of conflict and contradiction can always be undercut by the claim of their containment within a higher-order process that remains continuous. ${ }^{8}$

This analysis demonstrates good cause to question the assumption of congruence in tradition, including the modern conception of tradition as the development of doctrine. This questionability does not force the conclusion that traditional congruence is impossible. It does suggest, though, that claims for congruence must be carefully justified and cannot be naively assumed.

Suppose, though, that congruence were rooted in a developing tradition in some way or another so that its assumption were obviously warranted, and to such a degree that Tanner would cease to be concerned about all the issues she has raised. We would still need to explain how that congruence could be formulated in actual theological judgments, themselves exercises in doctrinal development. As noted, there is no shortage of methodological explanations for how particular theological judgments can be congruent. Certainly the most prevalent theological method in the modern tradition is some variety of correlation. According to this approach, the theologian's interpretive abilities synthesize past and present, resulting in a contemporary appropriation of the faith that is congruent with the former and relevant to the latter. This interpretive reconstruction requires three distinguishable moments in judgment: the theologian must understand the classical doctrine being reconstructed in its own historical context; the theologian must accurately assess the contemporary cultural circumstances within which the classical doctrine is being reconstructed; and, finally, the theologian must offer an interpretive reconstruction that is congruent with the past and meaningful to the present.

It is this third, synthetic moment in theological judgment that proves difficult to explain because it purports to offer something more in the act of interpretation that cannot easily be explained with the precision that method requires. As difficult as it may be to explain the first and second moments in interpretation, they yet aim at judgments contextualized by

${ }^{7}$ Ibid. 129.

${ }^{8}$ Ibid. 131. 
particular historical circumstances, whether past or present. Even though the object of interpretation in these moments may range from the concreteness of a carefully preserved text to the ephemeral character of a local mentality, interpretation at these levels is historically determinate, and kept so by a methodological awareness of the many particularities that might be factored into a viable interpretation. Thus, the task of method involves explaining the role of these particularities in the act of understanding. But the third interpretive moment presses beyond these relatively determinate parameters to posit a feature that transcends them-the congruence that the reconstructive theological judgment claims with the past.

Whether or not a particular theological judgment actually delivers on its claim for congruence is, of course, a matter of performance measured by further theological judgment. A community of interpretation may judge that a particular theological reconstruction fails to execute the method of correlation because it misrepresents either the authoritative past or the character of contemporary experience and, as a consequence of either failure, cannot achieve the relevant continuity expected of a successful act of correlation. Or, having accurately represented the interpretive poles of correlation, the execution of the method might be judged to fail because the interpretive synthesis lacks continuity or relevance or both. Performance aside, though, correlationist interpretation assumes that congruence is an achievable feature of the third moment of theological judgment.

There is nothing wrong with this assumption as long as it is shared in a community of interpreters which it well serves, and as long as interpreters do not exaggerate the capacity of theological method to explain the assumption beyond its claims. Typically, practitioners of the method of correlation are keenly aware of the fact that theological hermeneutics flourishes in the circle of faith. Sometimes, though, the concerns of correlation can suggest that its primary interpretive goal involves explaining the claims of faith to a broader public or even to a universal audience. If correlation is expected to proceed in this way, then the third interpretive moment is burdened with a weight it cannot bear. In this case, the explanation of the third moment is called upon to express the assumption of continuity that religious claims for tradition are wont to make and to do so in a manner cogent to those who do not share this assumption. This kind of explanatory overdetermination proceeds as though the theological use of a hermeneutical theory can convey universal meaning simply by virtue of its respectability in quarters beyond the community of faith. Yet, on closer examination, the theory invoked only offers the possibility of universality in understanding by investing some metaphor for epistemic reconciliation with remarkable explanatory power. Metaphors such as the "merging of 
horizons" (Horizontverschmelzung), ${ }^{9}$ the "fusion of past and present," 10 the "conversion" of the interpreter to the interpreted, ${ }^{11}$ "reflective equilibrium,"12 the "retrieval" of content in contemporary form, ${ }^{13}$ or even the term "correlation" itself, ${ }^{14}$ all attempt to convey the workings of the third interpretive moment, expressing at once the unity attributed to an authentic act of understanding and the congruence of tradition posited in that same unity.

Metaphors, however, do not possess the ability to ground understanding or traditional continuity. Functioning like a poetics of judgment, the metaphors express the epistemic reconciliation of the universal in the particular and, more specifically, the traditional reconciliation of past and present for which theological interpretation aims. To the degree that each of the metaphors can be invoked to convey both of these epistemic and traditional concerns at once, they are all the more valued as linguistic conveyors of what successful theological judgment hopes to achieve. But in themselves, the metaphors and the theoretical accounts they express do not validate anything at all. They do not explain how congruence actually happens in a theological judgment, only how the goal of congruence, the experience of congruence, or the claims of congruence might be expressed in images. The effect of the metaphor, one might say, is to express the assumption of congruence meaningfully claimed in a particular act of theological judgment. Images for agreement like those cited above, however, cannot explain how congruence actually takes shape in theological judgments.

${ }^{9}$ Many theologians have found this imagery, drawn from Hans-Georg Gadamer's Wahrheit und Methode, to be an effective expression of the hermeneutical project. See especially, David Tracy, Blessed Rage for Order: The New Pluralism in Theology (New York: Seabury, 1975) 78; also his, The Analogical Imagination: Christian Theology and the Culture of Pluralism (New York: Crossroad, 1981) 99-135.

${ }^{10}$ Roger Haight, S.J., Dynamics of Theology (New York: Paulist, 1990) 191.

${ }^{11}$ Bernard J. F. Lonergan, S.J., Method in Theology (New York: Herder and Herder, 1972) 235-66. In spite of Neil Ormerod's efforts to distinguish Lonergan's method (and, following Lonergan, Robert Doran's method) from correlation, I would place more stock in his concession that, on the face of it, Lonergan's (and Doran's) "project bears a strong resemblance to the description of the method of correlation" (Neil Ormerod, "Quarrels with the Method of Correlation," Theological Studies 57 [1996] 711). And rather than finding in Lonerganian "conversion" a non-arbitrary criterion for interpretive judgment, as Ormerod does (712-13), I would take the term to function as another synthetic metaphor for epistemic reconciliation.

${ }^{12}$ Francis Schüssler Fiorenza, Foundational Theology: Jesus and the Church (New York: Crossroad, 1986) 283-311.

${ }^{13}$ This has been an axiomatic discourse on the part of many late-20th-century Protestant and Catholic theologians.

${ }^{14}$ Paul Tillich, Systematic Theology, vol. 1 (Chicago: University of Chicago, 1967) 59-66; Tracy, Blessed Rage for Order 45-46. 
In making this point, I am not suggesting that theological judgments reached through correlation fail because the method's third moment only expresses the goal, experience, or the claims of congruence. The success of a theological judgment is measured by its acceptance in the community of faith, and theological judgments reached through correlation have been extraordinarily successful in this regard. But correlation is much better at offering methodological accounts of its first and second moments, in which no claim is made for congruence, than it is at offering a methodological account of the third moment, in which congruence is claimed. And to the degree that the third moment in correlation is much more a poetics than a methodological explanation, it does not explain how congruence comes to be formulated in theological judgment with the exactness one expects of method.

\section{THE PERSISTENCE OF ANALOGY IN CATHOLIC METHOD}

Another way of making the same point about the explanatory limits of correlation would be to note that this method takes its point of departure from the Kantian philosophical project and, more recently, from the phenomenological tradition represented by Heidegger, Gadamer, and Ricoeur. Here, the critique of traditional metaphysics issued in epistemologies that stressed the role of agency in understanding, an agency rooted in the transcendental conditions of subjectivity itself. However measured by its own historicity, transcendental subjectivity formally establishes the possibility of meaning in these philosophies and functions as the power of hermeneutical construction. Theologians found this philosophical approach useful not only because it defined a respectable current in modern thought but also because its account of rational agency could be appropriated methodologically. Correlationists from Schleiermacher to Rahner and his contemporary disciples have argued in various ways that the modern philosophical "turn to the subject" is fully realized in the act of faith, itself the consummate experience of self-transcendence. Mystical sensibilities could posit a tacit identity between the conditions of subjectivity (as noetic transcendence) and the act of faith (as transcendence toward God). This perceived compatibility between transcendental subjectivity and the act of faith allowed correlationists to see an agential unity between these experiences at work in the third moment of their method, with transcendental subjectivity supplying the conditions for the possibility of hermeneutical reconciliation and faith supplying the traditional congruence required in any successful interpretation. To the degree that this hermeneutical cooperation of transcendental subjectivity and faith promulgates mystical sensibilities, it is not surprising that its interpretive achievement is conveyed much more in metaphorical images than in exact, methodological explanation. 
As Catholic theology embraced modernity, hermeneutics overshadowed metaphysical analogy as credible method, at least on the part of the many theologians committed to apologetics. Metaphysical analogy made the doctrine of creation central to theological reflection, and thus gave ontology primacy over epistemology. The Kantian critique of traditional metaphysics undermined this long-standing conception of theology as analogical speculation, a philosophical stance that modern and postmodern hermeneutics regarded as intellectually axiomatic. The method of correlation appeared in theology as a viable alternative to metaphysical analogy. Its willingness to parse theological understanding through the historicity of interpretation satisfied post-Kantian concerns for the limitations of knowledge. Its diminishment of the doctrine of creation in theological reflection allowed the doctrine of grace to grow in methodological importance, especially as an unstated presupposition for how theological judgment reconciles past and present and achieves the value of congruence.

As much as analogy in a traditional key has been rendered theologically questionable, it is yet interesting to note how analogy has persisted as a theme in Catholic thought. In the early 20th-century, Erich Przywara articulated a distinctly modern version of the analogia entis that took account of both transcendental subjectivity and the metaphysical order as the common realm of creatureliness through which faith-filled reasoning encounters both the presence and otherness of God. Przywara's eclectic understanding of analogy even included a dialectical interpretation of the Cross, a classically Lutheran theme. Even though his treatment of analogy was untraditionally pluralistic in some respects, Przywara saw his work as a contribution to a theme consistently at the heart of Catholic thought. $\mathrm{He}$ insisted that metaphysical analogy is not merely one option among others within the Catholic heritage of reflection. "For the historical system of the Great Tradition (Ur-Tradition)," Przywara asserts, "appears not as something 'constructed out of' the analogia entis, rather, the analogia entis shows itself to be the rhythm of its inner movement." ${ }^{15}$ Even if Przywara's claim seems somewhat inflated in an age that increasingly has appreciated the pluralism of Catholic thinking, he is certainly correct to highlight the attractiveness of analogy for Catholic theology, even throughout the modern period. This attractiveness is evinced in the continuing appropriation and adaptation of analogy in the work of Etienne Gilson, Jacques Maritain, Joseph Maréchal, Emerich Coreth, David Burrell, and David Tracy. ${ }^{16}$

${ }^{15}$ Erich Przywara, Analogia Entis: Metaphysik: Ur-Struktur und All-Rhythmus, 2nd ed. (Einsiedeln: Johannes, 1962) 204.

${ }^{16}$ The observation about Gilson, Maritain, Maréchal, Coreth, and Burrell is Tracy's (The Analogical Imagination, 414). Recently, Robert Masson has called attention to the various ways in which analogy is understood in theological dis- 
Of these inventive thinkers, David Tracy has demonstrated the flexibility of analogy most of all by making it central to his own hermeneutical approach to theology, and so, with some measure of irony, appropriating for the modern trajectory of transcendental subjectivity an important dimension of the reflective approach it criticized. For Tracy, analogy is not a metaphysics but a rhetoric. It is a "language of ordered relationships articulating similarity-in-difference," a language that finally can find interpretive harmony among the plenitude of past and present forms that comprise a religious tradition. ${ }^{17}$ Moreover, analogy describes the creative workings of the theological imagination that is able to see similarity in difference, and through such vision to reach an understanding of how religious meaning illuminates self, society, history, and cosmos. Although that imaginative power finally takes its orientation from a specific religious tradition, it is not restricted to it but is capable of recognizing "the profound similarities-in-difference in all reality," ${ }^{18}$ and thus breaks open interpretive directions that are both particular and universal in scope.

The persistence of analogy in the Catholic tradition likely reflects basic Catholic beliefs about the relationship between nature and grace. Both metaphysical and rhetorical approaches to analogy affirm God's sacramental presence to the natural world, and the ability of the human person to respond freely to that presence, even, as the theologian does, by capturing the unity of God and creatures in theological homologies. The distinctiveness of analogy as a Catholic approach to theological reflection has even been accentuated by the modern era's concern for the particularities of method, especially those defined by confessional beliefs. The polemical exchange between Karl Barth and Przywara over the integrity of metaphysical analogy, and Hans Urs von Balthasar's charting of the debate in several writings, was influential in differentiating Catholic and Protestant methodological approaches as, respectively, "analogy" and "dialectic," the distinction itself a rhetoric expressing differing confessional commitments on the relationship between nature and grace. ${ }^{19}$

course, and to how the failure to appreciate this variety can lead to misunderstanding between theologians. Robert Masson, "Analogy and Metaphoric Process," Theological Studies 62 (2001) 571-96. I agree completely with Masson's implicit conclusion that the pluralism in conceptions of analogy means that analogical discourse is itself analogical, and recognize that this observation applies to the proposal I will offer in the pages that follow.

${ }^{17}$ Tracy, The Analogical Imagination 405.

18 Ibid. 410.

${ }^{19}$ Hans Urs von Balthasar, "Analogie und Dialektik," Divus Thomas 22 (1944) 171-216; idem, "Analogie und Natur," Divus Thomas 23 (1945) 3-56. See also James V. Zeitz, "Przywara and von Balthasar on Analogy," The Thomist 52 (1988) 473-98. For an interesting discussion of Barth on the analogia fidei, see Christopher 
It would be advantageous, I propose, to continue this Catholic devotion to analogy in theological method, not metaphysically in Przywara's style but linguistically in the approach broadly commended by Tracy. Although I have been critical of the method of correlation's ability to explain theological congruence with sufficient rigor, I remain convinced with Tracy that its attention to language rather than to ontology has accomplished much as a post-Enlightenment strategy, and with Tracy convinced too of the enduring value of analogy. In the pages that follow, I argue for a kind of linguistic analogy that describes more thickly how a claim for congruence actually appears in theological interpretation. As much as this analogy accounts for theological interpretation, it does not originate in theological thinking but rather in the way that believers make claims about tradition. Our consideration of congruence in theological judgment, then, must follow a discussion of analogy in tradition.

\section{TRADITION AS ANALOGICAL CONTINUITY}

A considerable amount of time and effort has been devoted to the topic of tradition in post-Enlightenment theology. Nineteenth-century theologians such as Johann Sebastian Drey, Johann Adam Möhler, and John Henry Newman proposed theories of doctrinal development that attempted to reconcile theology's new sense of historicity with long-held Christian claims about the continuity of tradition. Since the Second Vatican Council, a second wave in the theology of tradition has appeared in the work of theologians who challenged the a-historical sensibilities of neoScholasticism. Most notable among these was Yves Congar, whose magisterial $\mathrm{La}$ Tradition et les traditions promulgated an understanding of tradition as an active process involving the reception and, as Congar put it, re-reception of the authoritative teachings and practices of the past by contemporary believers. ${ }^{20}$ The reception model has become a kind of theological commonsense since the Council, embraced by the magisterium and theologians alike.

As one might expect, the assumptions at work in a modern understanding of tradition have shaped how theology itself is conceived and practiced. Doctrinal development assumes the historicity of meaning and the inescapably interpretive character of experience and its cultural construction.

Morse, "Raising God's Eyebrows: Some Further Thoughts on the Analogia Fidei," Union Seminary Quarterly Review 37 (1981-82) 39-49.

${ }^{20}$ Yves M.-J. Congar, O.P., La Tradition et les traditions, vol. 1: Essai historique (Paris: Fayard, 1960); vol. 2: Essai théologique (Paris: Fayard, 1963). Also, Yves Congar, "La 'réception' comme réalité ecclésiologique," Revue des sciences philosophiques et théologiques 56 (1972) 369-403. 
To the degree that theology is the practice of doctrinal development, these same assumptions enter its disciplinary repertoire, resulting in an understanding of theology as ever revisable interpretation and, lately, in theology's postmodern attention to the pluralism of meaning in local cultures. One would be hard pressed to find more particular influences of the theology of tradition on theological method itself, beyond, again, the general sense that method is assumed to be a thoroughly hermeneutical endeavor. ${ }^{21}$ Tradition tends to enter Catholic theological method as one of several "sources" of interpretation. Along with Scripture and experience, tradition has been conceived as a kind of interpretive ingredient that contributes its own measure of truth to the creative synthesis of theological judgment. Rather than understand tradition as a factor in theological interpretation, we would do better to regard it as the practice of faith that configures the congruence to which theological judgment aspires. Analogy offers an interesting way to imagine how such congruence is affirmed in the pattern of tradition.

Recently, I have argued for what I have called a "retrospective" understanding of tradition that traces the continuity of tradition from present to past, rather than from past to present. ${ }^{22}$ Premodern and modern conceptions of tradition typically imagine continuity as a given feature of every moment of traditional time, from the apostolic age to the present. A premodern conception of tradition sees such continuity unchangingly manifest in the orthodox faith and practice handed down by every generation to the next. A modern conception of tradition as the development of doctrine sees such continuity as at least latent in every moment, and manifesting itself gradually as history unfolds. Both premodern and modern conceptions envisage tradition prospectively. They imagine tradition from the perspective of an idealized observer at its beginnings in the apostolic age looking forward into the future, across the ages, and seeing the one and same continuity, or at least its possibility, in every time. This prospective optics actually imagines tradition from a divine perspective, since only God could envision tradition in this manner. The attractiveness of this forwardlooking optics is that it clearly affirms the unbroken history of continuity expected by premodern and modern conceptions of tradition.

A retrospective understanding of tradition relinquishes this divine per-

${ }^{21}$ Lonergan articulated well this general influence of historical sensibilities on theology: "When the classicist notion of theology prevails, theology is conceived as a permanent achievement, and then one discourses on its nature. When culture is conceived empirically, theology is known to be an ongoing process, and then one writes on its method" (Bernard J. F. Lonergan, S.J., Method in Theology [New York: Herder and Herder, 1972] xi).

22 John E. Thiel, Senses of Tradition: Continuity and Development in Catholic Faith (New York: Oxford University, 2000) esp. 84-95. 
spective, which no creature may have, and configures traditional continuity from the present moment in ecclesial life. Tradition, after all, is a corporate act of faith that the Church makes about when and where and how God's Spirit has truthfully wended its way through history. This corporate claim is a consensus drawn from many individual acts of faith that are always situated in a present moment and which, from that present moment looking backward, affirm a particular belief about the presence of the Spirit through time. This retrospective affirmation is the Church's belief about the continuity of tradition. As much as continuity can be imagined as a fixed commodity abidingly present from the earliest Church to the present, it is, in actuality, a retrospective claim about the unity of tradition that continues only as long as it is presently believed. What moderns have conceived as the development of tradition unfolds in perceptible changes in how the pattern of retrospective continuity is modified in successive present moments. And if the continuity of tradition lies in the claims of corporate acts of faith developing in time, then what modern theories are inclined to distinguish as the "continuity" of tradition and the "development" of tradition are actually the same thing.

Saying that the "continuity" and the "development" of tradition are actually the same thing might suggest a position quite like Tanner's, with its deep suspicion of any real continuity in tradition beyond the ongoing, historical debate among Christians about what tradition is. A retrospective understanding of tradition, however, affirms real continuity as a claim that Christians make about the unity of tradition from their own times back to the apostolic age. Certainly there are some Christian claims-such as the profession of Jesus as savior, the indispensability of grace for salvation, and the hope of resurrected life-that believers have made consistently from the beginnings of the tradition to the present. And yet, even these relatively settled and uncontroversial claims for tradition continue to flourish as retrospective acts of faith, developing if only in their stolid reaffirmation. More surprising affirmations of continuity occur as any particular generation of believers layers these more stable lines of tradition with new claims for retrospective continuity that may develop, slowly or quickly, into present claims for the apostolic tradition. By the same token, a strand within tradition's long-held claims may atrophy, slowly or quickly, to the point that a particular generation judges the belief to be incredible, and so no longer the Church's tradition. Through the reaffirmation of the truly old, the accretion of the relatively new, or the shedding of the old but obsolete, the entire community of faith comes to affirm a developing continuity that, in any present moment, may look quite like the faith of times long past in some respects, and quite different from the claims of earlier believers in other respects.

This retrospective understanding of tradition, then, understands conti- 
nuity to be thoroughly temporal, as all things traditional are, and measures the time in which continuity is claimed in faith from present to past. So understood, the continuity of tradition develops at once repetitively and dynamically, as old configurations of continuity are reaffirmed alongside new affirmations of continuity for addition and loss that are often mutually related. What I would call the "literal sense" of tradition ${ }^{23}$ lies in present claims for continuity that are uncontroversial, not because their meaning is judged to be trivial but because there is a real consensus among believers about the truthfulness of these claims as the age-old faith of the Church. Many of the claims of the literal sense, like those cited above, are historically old and are continuous by virtue of their repetition in every generation of believers. But claims for the literal sense in any historical moment in which they are affirmed need not be historically old, even though they are claimed in faith as the apostolic tradition. A good example of the latter would be the teaching of the Second Vatican Council's "Declaration on Religious Freedom" (Dignitatis humanae) which portrayed the freedom of religious belief as a sacred right revealed by God, and so a teaching rightly placed within the apostolic tradition, even though this teaching was neither believed, nor taught, nor practiced in the previous history of the Church, and defined rather suddenly in $1965 .^{24}$

This understanding of traditional continuity can stand before the criticisms advanced by Kathryn Tanner and examined earlier. ${ }^{25}$ As devastating as Tanner's position may be for any fundamentalist understanding of traditional continuity, its deep suspicion of any real continuity in tradition fails to acknowledge that the literal sense of tradition is a claim that a particular Christian community makes in faith retrospectively. Tanner advances her argument against synchronic continuity, one notices, by making an ahistorical and idealized "Christianity" the measure of synchronic and diachronic continuity. But "Christianity"-what all Christians believe-is an abstraction that does not exist "on the ground," the very place from which Tanner's anthropological approach gathers its evidence. Synchronic continuity actually exists more modestly in history in specific Christian traditions shaped by particular kinds of agreement in faith. Present-day agreement, for example, certainly does not exist between all Christians on a doctrinal issue like the relationship between nature and grace. And yet, Roman Catholic Christians in the present historical moment do indeed

${ }^{23}$ Ibid. 31-55.

${ }^{24}$ Dignitatis humanae (Declaration on Religious Freedom) nos. 2-3. Translation from Decrees of the Ecumenical Councils, vol. 2, ed. Norman P. Tanner, S.J. (Washington: Georgetown University, 1990) 1002-04.

${ }^{25}$ This, of course, is a claim of mine with which Tanner would not agree. See the exchange between Tanner and me on this very point in "Editorial Symposium: Roman Catholic Theology of Tradition," Horizons 29 (2002) 303-11, 318-21. 
share a belief about this same matter. Tanner's argument against diachronic continuity is simply that the evidence of history does not warrant such a claim. But this judgment wrongly makes chronological history the measure of traditional continuity, itself a claim made in faith about the temporal pattern of divine truth and providence. Judged against this standard, it is hardly surprising that traditional continuity evaporates like morning dew in the sun. Even though faith-claims for traditional continuity are in history and so are a part of the historical record of Christianity, they can no more be theologically measured by chronological history than the truth of the gospels can be measured theologically by the Jesus of history or the resurrection of Jesus can be measured theologically by the laws of physics.

Understood retrospectively and particularly, the literal sense of tradition runs counter to the direction of chronological time as the Church's contemporary, and developing, affirmation of how its belief, doctrine, and practice stand in continuity with the faith of the apostles. As an act of faith, this affirmation of congruence is no mere possibility but instead the most ordinary of actualities in the daily life of the Church, and one that believers attribute largely to divine grace. Tanner, then, is correct to point out that the congruence of tradition is a very large assumption indeed, as the claims of faith always are.

To say that claims for the congruence of tradition are claims of faith, however, should not be invoked as an explanatory panacea. If present-day claims for a particular configuration of the apostolic tradition differ from the claims of earlier generations of believers, then explaining how this can be so, contrary to the historical record, is incumbent on any theology of tradition worth its salt. A premodern understanding of tradition is unaware of the historical record and so is able naively to regard present-day claims for the apostolic tradition as what every previous generation believed in exactly the same way. Here, difference is heretical deviation. Aware of the historical record, a modern understanding of tradition as the development of doctrine regards the historical absence of present-day claims for the apostolic tradition as latency through which later developments have grown. Here, difference is potential. A premodern understanding of tradition held in the modern period, i.e., fundamentalism, denies the truth of the historical record of which it is aware. Here, difference is the perdition of a merely secular account of reality. None of these explanations is adequate-neither the premodern understandings for their naïve or willed ignorance of the facts of history nor the modern understanding for its recourse to a romantic metaphysics of essence and manifestation to explain the gaps in the history of doctrine.

The retrospective model addresses the problem of continuity and change by regarding congruence as a claim made in faith by present-day believers 
about how they stand in a line of truth that extends back to the apostolic age. It is a claim that can neither be ignorant of chronological history nor beholden to it. Claims for congruence presently affirmed as sacred tradition often cannot be justified by the evidence of chronological history, as Tanner rightly points out. And yet, those even centuries-long gaps in the historical record would only subvert a faith-claim for a particular pattern of continuity if one assumed that claims for the apostolic tradition were historically identical with the retrospective claims of faith made in the apostolic age, or if one assumed that traditional continuity requires chronological justification in order to be true. A retrospective understanding of tradition would share neither of these assumptions.

Retrospective claims for the continuity of tradition can find their way through the brokenness of chronological history by tracing the Spirit's abiding presence through the retrospective claims of previous generations of believers all the way back to the apostolic age. As long as such a presentday affirmation of apostolic continuity recognizes that it is a claim made in faith about sacred time, the gaps in the historical record need not prove defeating. A good example of such a retrospective claim for apostolic continuity in the face of chronological history can be found in the presentday Catholic literal sense belief in the Immaculate Conception of Mary. Historical study shows that this belief did not become popular until the 14th century and that, prior to that time, no less an authority than Thomas Aquinas found it to be incredible. ${ }^{26}$ In principle, the belief that Mary, the Mother of God, was herself conceived without original sin could not have been widely held by Christians prior to Augustine's fifth-century definition of the doctrine of original sin in the Pelagian controversy. And yet, Pius IX, in his solemn definition of the dogma in 1854, described it as "a doctrine revealed by God... [which] therefore must be firmly and constantly held by the faithful," 27 as it indeed was by the 19th century. Explained retrospectively, this claim for apostolic tradition can be justified by finding a pattern of continuity that stretches backward from the present-day claim, to the increasing belief in the doctrine since the 14th century that united even earlier retrospective beliefs about the sinlessness of the Savior, the dignity of Mary as the Mother of God, and Augustine's development of Paul's strong conception of human fallenness. Thus construed from present to past in solidarity with previous generations of believers, a present-day claim for apostolic continuity can traverse the gaps of chronological time.

${ }^{26}$ Summa theologiae 3, q. 27, a. 3.

27 Enchiridion symbolorum definitionum et declarationum de rebus fidei et morum, 34 ed., ed. H. Denzinger and A. Schönmetzer (Freiburg: Herder, 1965) no. 2803. English trans. from The Church Teaches, ed. and trans. J. F. Clarkson, S.J., et al. (St. Louis: B. Herder Book, 1955) 208. 
We might conceive of this way of configuring continuity as an exercise in the analogy of faith and, to the degree that faith may be expressed as claims about the Spirit's presence to history, as an exercise in the analogy of tradition. Analogy posits meaningful similarity-in-difference in whatever dimension of reality the analogue highlights, whether in language, or experience, or in being. Here, our focus on traditional faith-claims leads us to attend to analogy from a linguistic perspective, while regarding that language as inseparably bound to the experience it expresses and shapes, and to the being to which language refers. Claims about tradition are thoroughly analogical. In professing the unity of tradition, believers give voice to a belief or enact a practice that most obviously is theirs, but which also is claimed as the belief and practice of others, and which so, on another level, is belief and practice other than theirs. These "others" are both contemporary believers who are not distant in time but who may be relatively distant in culture, and believers long dead who are distant in culture and time as well. Yet, in professing the unity of tradition, believers affirm that their faith and practice, both diachronically and synchronically, is like the belief and practice of these others, in spite of the striking differences in time, place, circumstance, and culture that divide them. This analogical likeness is not claimed as a mere casual resemblance. Perceived through the eyes of faith, analogical likeness is the deep congruence of a shared faith capable of binding the tradition from present to past. It is an analogical continuity justified by the oneness of the body of Christ, and marking the truthful presence of the Holy Spirit through time, place, circumstance, and culture.

At first glance, the most steadfast, literal sense claims of tradition, which even historical investigation shows have been affirmed throughout the ages, might seem to transcend this analogical similarity-in-difference by virtue of their continuous repetition. Yet, on closer examination, even these long-standing claims, which flourish only in their present affirmation, are always somewhat different from the past claims they ardently reaffirm. Even as reaffirmations of the tradition, the present claims for the age-old tradition are ever made anew, and so each act of faith posits a difference that must be at once appreciated and transcended in the claim for continuity. At the heart of this dimension of tradition we meet a continuity solidified within a remarkable pluralism of dissimilar times and cultures. Within this pluralism of time and place we find an even greater pluralism of individual acts of faith, the most recent faithfully striving to find in those that came before an analogue to their own claims for the apostolic truth.

Literal sense claims that are more circumscribed historically, like the dogma of the Immaculate Conception or Vatican II's teaching on religious freedom, may also be conceived through the image of analogical continuity. Here, though, the more extensive historical gaps that faith must retro- 
spectively traverse require that analogical similarity be found not only in acts of faith across time and culture but also in various doctrines defined throughout the tradition as common acts of faith. Although these doctrines are by no means the same, believers find a homology between them that becomes the basis for their present-day claim for apostolic continuity. Once again, the Immaculate Conception of Mary may serve as an example. Latter-day believers in the dogma affirm it as abiding tradition by finding a real homology among the doctrines it presupposes and affirms as a claim about the Mother of God, doctrines such as the sinlessness of the Savior, the dignity of Mary, and Augustine's further strengthening of Paul's already strong conception of sin. This homology extends across time in a way that the evidence of chronological history does not, and forms a continuity that contemporary believers analogically may trace back to the earliest beliefs of the apostles.

The relations between and among claims for the old (even if not historically old) are not the only kind of analogy that can be identified in the workings of tradition. The traditional reiteration of old claims in the present moment is often accompanied by claims for the traditionally new. These novel claims cannot be regarded as authoritative tradition since they lack the deep consensus on the part of the whole Church that literal sense tradition requires. Nonetheless, the minority of the faithful who make a novel claim profess the belief that their claim deserves to be recognized as the age-old faith of the Church even if historical investigation clearly shows that their claim was not previously believed in the way it is presently articulated. Nearly every literal sense claim of the tradition was once a novel claim, which means, of course, that the development of tradition proceeds as the new is embraced, quickly or slowly, as the old. Contemporary minority beliefs and practices like gender-inclusive symbolism of God, the ethical authority of the preferential option for the poor, and the new argument that the restriction of priestly ministry to males is divine revelation are all examples of novel claims of faith that may or may not prove to be authoritative tradition with the passing of time. ${ }^{28}$

Believers advance novel claims on behalf of tradition, at least implicitly, by finding analogues within the recognized authority of the literal sense that justifies their claims for congruence. These analogical connections between the literal sense and novel claims are always tenuous, since here analogical similarity faces a difference that is scandalous and marked by both the strangeness and the minority status of the claim. Difference in this regard is no longer merely the dissimilarity of re-affirmation in many times and places but the threatening difference of apparent deviation that yet claims orthodoxy. If the novel claim eventually becomes literal-sense tra-

\footnotetext{
${ }^{28}$ For an elaboration of the examples, see Thiel, Senses of Tradition 139-49.
} 
dition, this threatening difference will be transformed into the customary difference of repetition as the whole Church increasingly affirms the analogical similarity between the new belief and the literal sense to the point that the latter engulfs the former. It is important to note too that this development may unfold at the same time through judgments in faith measured by what we might call "disanalogy." Often, though not always, claims for the traditionally new are accompanied by claims that some longstanding belief or practice has become questionable or even rejectable, and so disanalogous with a re-configured analogical continuity that binds the tradition into a whole. ${ }^{29}$

Since the 19th century, theologians have proposed several images for the development of doctrine, among them, Johann Sebastian Drey's notion of a productive "dialectic" of past and present faith, John Henry Newman's noetic metaphor of doctrines as ideas in process of clarification, and 20thcentury appeals to ongoing "reception" on the part of believers. Invoking the image of analogy to account for the development of doctrine might be felicitous for several reasons. First, and as noted earlier, analogy has been a template for describing the God-world relationship throughout much of the Catholic tradition, perhaps because analogical homology reflects the deeply sacramental spirituality of the Catholic tradition expressed especially in its beliefs in the eucharistic Real Presence, the knowability of God through creation, and the human person's capacity for free response to the offer of grace. Second, employing the category of analogy in a theology of tradition interprets the tradition by appeal to a traditional conceptualization and rhetoric, a theological approach that affirms the resiliency of the tradition as a source of meaning. Third, and finally, enlisting analogy to explain traditional similarity in the face of historical difference fits well with the retrospective account of tradition presented here. Analogy offers a way of appreciating how a present-day faith, looking to configure its authoritative heritage back to the apostolic age, finds homologies through a past rife with differences between what Christians claim as tradition today and what Christians did or did not claim as tradition in any previous historical moment. The analogical image conveys the assumptions of the retrospective model, particularly its expectation that the unity of tradition continues to be tempered by historical difference and yet may be meaningfully affirmed in spite of historical difference.

Analogy, of course, could be put to the service of a prospective account of tradition, and tacitly often is. But when it is, an established tradition tends to see only itself in the latest passing moment, assuming, contrary to the evidence of history, that the continuance of tradition will reiterate only what has been. Here analogical homology breaks down, losing its rightful

${ }^{29}$ See ibid. $100-28$. 
appreciation for the differences that ever contextualize similarity and giving way to a narcissistic fixation on tradition's customary face. It is precisely in this regard that the Fourth Lateran Council's "rule of faith" on analogy might be applied, not in the metaphysical context in which it was originally defined but in the linguistic setting of a theology of tradition. The teaching of the Council-that "between creator and creature there can be noted no similarity so great that a greater dissimilarity cannot be seen between them"30 - should remind us that tradition is the Church's ongoing, and very tentative, effort to name the presence of God's Spirit in history. Portrayed as analogical homology, traditional continuity names the Spirit's presence in a particular configuration of belief, doctrine, and practice from present to past. ${ }^{31}$ But however much confidence the Church places in its naming of traditional continuity, it must be ready to acknowledge that its naming is never adequate to what is being named, not only because God is beyond human naming but also because God's gift of the Spirit continues to course through history in surprising ways that should undermine any sense that what the Church claims as the continuity of tradition has been utterly settled.

\section{ANALOGY IN THEOLOGICAL METHOD}

Now we are ready to attempt an answer to the question of how congruence is achieved in theological judgment. The workings of tradition sketched above will point the way to our answer. First, though, we should state what our answer will not be. We will not address this question in a Kantian manner, taking it to be a question about the transcendental conditions that attend the theological task. That kind of question is asked when theology is regarded first and foremost as an exercise in apologetics, and theologians have the utmost concern to justify what they do before the court of reason at-large. Our approach to the question should measure the possibility of theological judgment by what faith actually does, in cooperation with reason, in making a theological judgment. The context for asking and answering the question should be the community of faith in which asking and answering takes place first and foremost as an exercise in ecclesial responsibility and self-understanding, and not as an exercise in selfjustification.

Congruence in theological judgment is achieved as theological judgment

${ }^{30}$ Decrees of the Ecumenical Councils, vol. 1, ed. N. P. Tanner, S.J. (Washington: Georgetown University, 1990) 232.

${ }^{31}$ I assume, though it is worth noting, that the field of analogical relations that I have here called "tradition" includes Scripture, and that believers draw primarily, but not exclusively, from God's revelation in Scripture in making claims for analogical continuity. 
follows the actual lines of congruence shaped by faithful judgments about traditional continuity. Christian communities constantly chart their claims for the congruence of tradition by re-affirming long-held lines of continuity, adjusting new claims for tradition to these well-hewn paths back to the apostolic age, and occasionally leaving behind past claims that the community no longer finds worthy of belief or practice. The congruence claimed in theological judgment is the very same congruence that different acts of faith make in positing a particular configuration of traditional congruence. The congruence claimed may be a time-honored line of literalsense continuity that charts the tradition's most basic beliefs. Or the congruence claimed may be a new affirmation of continuity that configures the ancient tradition in a somewhat different way, but which yet clamors for recognition as the rightful authority of the past. Typically, theological representations of literal-sense congruence proceed aesthetically by way of description, while theological representations of novel congruence proceed forensically by way of argumentation. Any theology, though, makes its case for truthfulness by adjusting its judgments to a particular pattern of analogical continuity that stretches, retrospectively, from present to past. A judgment for theological congruence may be very much like the act of repetition that any claim for literal sense tradition is, finding truth in an analogical homology weighted decidedly on the side of traditional similarity. Or a judgment for theological congruence may bind beliefs across time unusually, finding truth in an analogical homology that appreciates creative difference and envisions tradition in new ways. In either case, theological judgments for congruence mirror traditional judgments for congruence. The practice of theology, rightly understood, is the practice of tradition.

We might think of theological judgments for congruence as specialized forms of traditional judgments for congruence. Their specialized character is a function of the knowledge that theologians possess about the historical dimensions of tradition, a knowledge that most believers throughout the tradition have lacked. While all believers encounter tradition holistically in the living intersections of belief, practice, and worship, theologians are able to conceive of tradition in a linear way and to perceive how the analogy of tradition configures continuity in ways that run counter to a faithless chronology of the past. This knowledge presents no advantage to faith. But it does enable theologians to understand how the development of doctrine has transpired throughout Catholic tradition and to appreciate the contributions of theological judgment to that process. Theological judgments for congruence are an important way, though not the only way, of bringing the tradition under reflective scrutiny so that ancient claims for analogical continuity may once again be affirmed meaningfully in the present moment or so that new claims might be ranked analogically among the treasures of the past in spite of their chronological audacity. As an exercise in the 
development of doctrine, the theological judgment for congruence has a role in shaping the very same traditional judgment for congruence that it mirrors.

This close relationship between theological judgment and traditional judgment should be reflected in methodological considerations of the theological task. I propose that we think of theological method as the analogy of tradition, since the congruence to which theological judgment aspires is achieved by drawing the same analogical lines of continuity between present and past that traditional judgments draw in developing the tradition in every passing moment. ${ }^{32}$ Delineating this theological method would be no different from describing the various ways in which faith analogically claims the congruence of tradition. And this, in turn, means that the method of theology lies in the exercise of traditional faith itself, most especially at the point that method explains how congruence in theological judgment is achieved. Method is not something imported into theology to explain the possibility of theological judgment but is itself an implementation of that same faithful judgment.

From a certain perspective, this might seem to be a claim falsely inflated in its simplicity, and one that runs counter to the current proposal. Analogy, a critic might object, is not traditional faith but a theoretical account of how faith is construed historically. And once enlisted into theological service, analogy behaves like any theory of correlation, biting off far more than it can chew in accounting for how theological judgment achieves congruence. Although I would be willing to concede that analogy is a theory, I would argue that its interpretive history in Catholic theology demonstrates its compatibility with the basic claims of faith that it explains, even to the extent that analogical discourse has entered the rhetoric of faith in the Catholic tradition. Moreover, the analogy of tradition, as presented here, explains what faith has done in the past and what faith continues to do in the future. Analogical thinking finds meaningful patterns of unity through the confusion of linguistic, experiential, and metaphysical plurality. The analogy of tradition is shaped as the whole Church together finds the authoritative continuity of tradition through the chaos of chronological time. Proposed here as theological method, the analogy of tradition is a way of understanding the actual use to which theological judgment puts a particular claim for congruence. ${ }^{33}$ Finally, that interpretive use can only be

${ }^{32}$ My proposal that theological analogy be conceived as a judgment made in faith claims continuity with Aquinas's understanding of analogy rather than with Cajetan's conceptualist approach. See Gregory P. Rocca, O.P., Speaking the Incomprehensible God: Thomas Aquinas on the Interplay of Positive and Negative Theology (Washington: Catholic University of America, 2004) 154-95.

${ }^{33}$ David Burrell has proposed an understanding of analogy as use. David Burrell, 
measured against the use to which the Church puts its claims in faith for traditional congruence.

Analogy thus understood is not a special theory imported as a relevant means for parsing the experience of the Church. It is a way of imaging the remarkable process through which the Church professes the distinctive presence of God to history, a presence that surprises as much as it steadfastly abides. Special theories may aid in explaining the first and second moments of correlation, in recovering the ancient past or in elucidating the present moment. But they cannot explain how traditional or theological congruence between those moments is achieved. Traditional or theological congruence is finally achieved by grace, and the analogy of tradition describes how faith gracefully and actually claims divine pattern in history. It may be that the metaphors of reconciliation that convey the act of synthetic judgment in the method of correlation's third moment are but stylized ways of describing the use to which a theological judgment of congruence is put. But if so, then there may be advantage to realizing what actually transpires beneath the style, as well as in knowing that the conditions of the possibility of theological congruence in no way make congruence actually happen. ${ }^{34}$

C.S.C., Analogy and Philosophical Language (New Haven: Yale University, 1973) esp. 215-51. A family resemblance to this proposal can be found in Donald Davidson, "What Metaphors Mean," in Inquiries into Truth and Interpretation (Oxford: Clarendon, 1984) 245-64.

${ }^{34}$ I express my gratitude to Nancy Dallavalle, Paul Lakeland, Robert Masson, and to the members of the New Haven Theological Discussion Group for their valuable criticism of an earlier draft of this article. 